\title{
WestVirginiaUniversity
}

THE RESEARCH REPOSITORY @ WVU

Graduate Theses, Dissertations, and Problem Reports

2001

\section{Pest management practices used by West Virginia corn growers}

Leasa Dianne Wilkerson

West Virginia University

Follow this and additional works at: https://researchrepository.wvu.edu/etd

\section{Recommended Citation}

Wilkerson, Leasa Dianne, "Pest management practices used by West Virginia corn growers" (2001). Graduate Theses, Dissertations, and Problem Reports. 1331.

https://researchrepository.wvu.edu/etd/1331

This Thesis is protected by copyright and/or related rights. It has been brought to you by the The Research Repository @ WVU with permission from the rights-holder(s). You are free to use this Thesis in any way that is permitted by the copyright and related rights legislation that applies to your use. For other uses you must obtain permission from the rights-holder(s) directly, unless additional rights are indicated by a Creative Commons license in the record and/ or on the work itself. This Thesis has been accepted for inclusion in WVU Graduate Theses, Dissertations, and Problem Reports collection by an authorized administrator of The Research Repository @ WVU. For more information, please contact researchrepository@mail.wvu.edu. 


\title{
PEST MANAGEMENT PRACTICES USED BY WEST VIRGINIA CORN GROWERS
}

\author{
Leasa D. Wilkerson
}

Thesis submitted to the Davis College of Agriculture, Forestry and Consumer Sciences at West Virginia University in partial fulfillment of the requirements for the degree of

\author{
Master of Science \\ in \\ Agricultural Education
Layle D. Lawrence, $\mathrm{PhD}$, Chair Stacy A. Gartin, PhD
John F. Baniecki, PhD

Division of Resource Management

\author{
Morgantown, West Virginia \\ 2001
}

Keywords: Agriculture, Corn Production, Extension, Pest Management 


\section{ABSTRACT \\ PEST MANAGEMENT PRACTICES USED BY WEST VIRGINIA CORN GROWERS}

Leasa D. Wilkerson

The purpose of this study was to provide information that might be useful to researchers and extension personnel at West Virginia University in developing and designing educational programs concerning pest management for corn farmers. This research identified current trends in management practices, insect, fungal, and weed problems, and educational needs so that instructional materials can be designed to meet clientele needs. Data were collected via 100 questionnaires mailed to farmers in the top ten corn producing counties in West Virginia. Of these, thirty-three useable surveys were returned.

It was found that Gray leaf spot and Maize virus were the most prevalent diseases; Johnson grass, Pigweed and Fall panicum were the weeds most injurious; Corn borer, Stalk borer, and Root worms were the most injurious insects; and, of vertebrates, deer were the most common pests affecting West Virginia corn producers. Field inspections, cultivation, and use of pest thresholds were the most common control measures used by farmers. 


\section{DEDICATION}

This thesis is dedicated to Mr. Gilbert Wilkerson, my grandfather and next-door neighbor, for inspiring me to be a hard worker and good citizen, to love what you are doing and to be successful in life. 


\section{ACKNOWLEDGEMENTS}

First, I wish to express my gratitude to Drs. Layle Lawrence and Stacy Gartin, faculty members in Agricultural Education at West Virginia University. With their help, I have experienced a well-rounded graduate experience. The agriculture teachers in West Virginia are very lucky to have both of you available for guidance.

Very sincere appreciation is expressed once again to Dr. Lawrence, academic advisor during my graduate program as well as chairman of the graduate committee, for his guidance throughout the writer's endeavors and for his endless patience, many emails, and encouragement during this task. Nothing I write here can adequately show my sentiments for this man nor repay for his unselfish friendship. I was lucky to have an incredible graduate committee including Drs. Stacy Gartin and John F. Baniecki. I would like to thank Dr. Gartin for his endless cheerfulness and guidance and Dr. Baniecki for the opportunity to work in his lab and for his insight and knowledge of subject matter.

I would like to thank Jacquie Stuart, Charles Rosenkrans, Ben Gallop, Cheryl Nestor, Lisa Ferguson, Scarlet Dalrymple, Angela Meierotto, Pragathi Shetty, Urmila and Satrajit Das, Deliese Metcalf, Emily Wilkins, Sue Coty, Rhonda and Cliff Myers, Donald Burgess, Deborah Steele, and Melissa Thorton for their friendship. Your encouragement and support helped me throughout the years.

Lastly, I thank the most important people: my family, mother and father Bob and Margaret, brother Robby, nephew Austin, Aunt Martha, my cousin 
Michele and my husband Nanda Ponnappa Gudderra for being patient and supportive. Special thanks to my husband who encouraged me over the last eight years to continue my education and to inspire me to reach goals that I did not know I could grasp. Thank you for all that you have done. A big "thank you" to those l've missed. 


\section{TABLE OF CONTENTS}

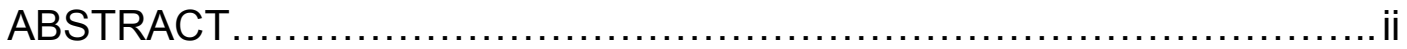

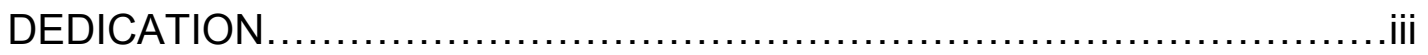

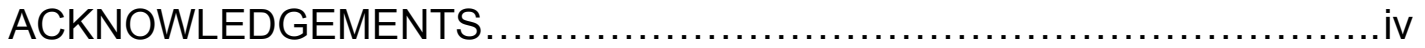

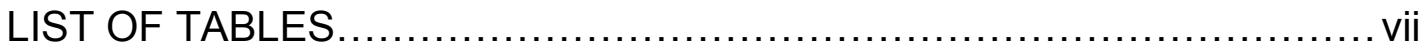

CHAPTER

I. INTRODUCTION ................................................................. 1

Statement of the Problem ............................................. 3

Purpose and Objective............................................. 4

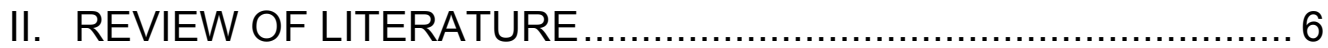

III. RESEARCH METHODS AND PROCEDURES ....................... 10

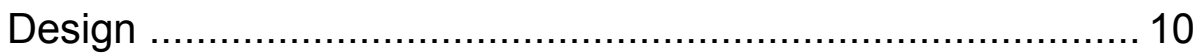

Population and Sample............................................ 11

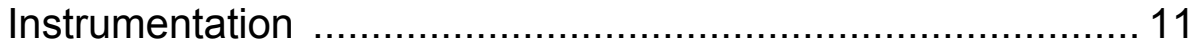

Administration of the Instrument ................................... 12

Data Analysis ............................................................ 13

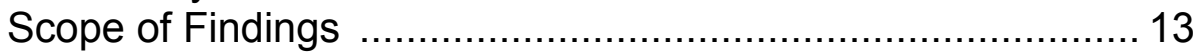

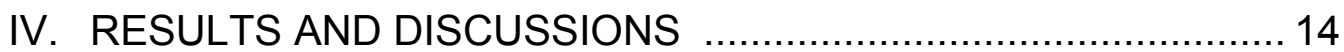

V. SUMMARY, CONCLUSIONS AND RECOMMENDATIONS

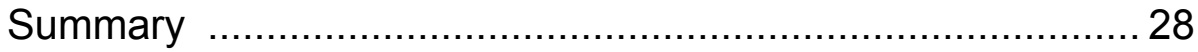

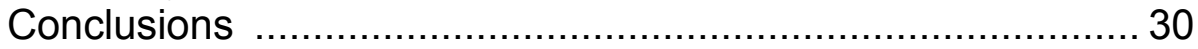

Recommendations …............................................... 31

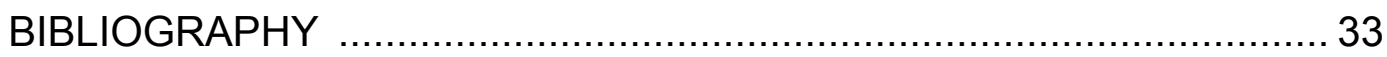

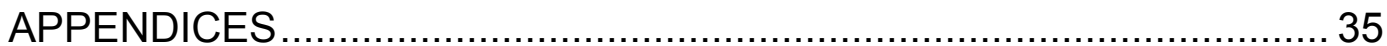

APPENDIX A Letter to County Extension Agents .................... 36

APPENDIX B Cover Letter to Participants .............................. 38

APPENDIX C Questionnaire ........................................ 40

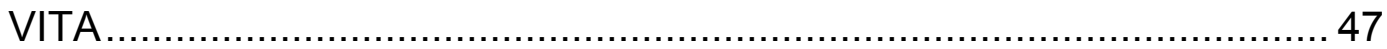




\section{LIST OF TABLES}

Participants of the West Virginia Corn Growers Pest Management Survey: Number of Respondents and Acreage of Corn Production

Severity of Diseases Perceived by West Virginia Corn Growers in 1999

Severity of Problems Caused by Weed Pests Perceived

by West Virginia Corn Growers in 1999

Severity of Arthropod Problems Reported by West Virginia Corn

Growers in 1999

Corn Growers' Perception of the Severity of Problems Caused by Vertebrate Pests in West Virginia

Selected Control Measures Used by West Virginia Corn Growers ..... 23

Sources of Information Regarding Pest Problems Used by

West Virginia Corn Growers

Informational Needs of West Virginia Corn Growers 
Chapter I

INTRODUCTION

Zea mays Linnaeus, known as corn in the United States and as maize in most other parts of the world is a monoecious grass, and is the most widely grown crop in the world. The cultivation, genetics, processing, financing and distribution on an international scale makes corn a major cash crop in the United States (Pedigo, 1996). Corn is produced for silage, grain, seed, and fresh market produce and feed grain corn is the most commonly grown occupying more than sixty-five million acres in the United States (National Agriculture Statistical Service, 1996)

Additionally, corn plays an intricate part in the basic grain rations fed to swine, sheep, poultry, beef cattle and dairy cattle in the United States. Seventyfive percent of grain corn produced in the United States is fed to livestock. Twelve to fifteen percent of corn is processed for human consumption. The importance of corn to human consumption can be seen in production of certain industrial products such as cornstarch, corn sugar, corn oil, corn meal, corn hominy, grits, tortillas, and cereal. Industrial products originating from corn are butyl alcohol, lactic acid, acetone, corn starch-based plastics, corn syrup, and ethanol (Magness et al., 1971). The United States produces $41 \%$ of all corn grown in the world with a cash value of 12.1 billion dollars.

Although, West Virginia is not a major corn producing state, corn is a major crop grown on farms in the state. According to the West Virginia Agriculture 1997 Census, 27,642 acres were primarily grown for silage or green 
chop and 35,499 acres grown as grain for livestock (United States Department of Agriculture Census, 1998). The total number of farms in West Virginia was 17,772 amounting to $3,455,532$ acres. Thirty-eight percent of this acreage $(63,100$ acres) was in cropland and half of it was kept as pasture (USDA, 1998). However, crop loss due to damage by insect pests of corn in WV is not known. Damage is magnified when corn is grown continuously on the same land. This continuous monoculture reduces the soil's ability to sustain the crop. The weakened crop is then a perfect site for the buildup or attack of insects such as rootworms and corn borers.

More than thirty species of insects, thirty annual and perennial weeds, and fifty-disease pathogens cause damage to corn (Pedigo, 1996). Historically, control measures usually consist of selection of varieties resistant to certain diseases and insects. Cultural practices such as crop rotation and tillage methods were devised by growers in hopes of reducing losses caused by corn borers. Two pests that make up the majority of damage to field corn in the Corn Belt (North Central States) are the Northern corn rootworm and the European corn borer. Combined, these two pests rank in the crop's top need for insecticides (Pedigo, 1996). Therefore, good management practices are the key to controlling pests and making a profit.

Pest management is known as control of noxious and damaging organisms including insects, mites, nematodes, plant pathogens, weeds, and vertebrates. Insects make up $75 \%$ of the world's animal species and are considered the most frequent pests of humans (Flint and Van den Bosch, 1981). 
A pest is recognized as an organism that competes with humans for food, fiber, and/or shelter. Pest control tactics are designed to disrupt the insect's life cycle and is an essential component of the crop protection system (Pedigo, 1996). Various pest control measures exists, however, during the last four decades use of chemical pesticides has become the predominant method of controlling pests. The very success of pesticide chemicals has led to a heavy reliance on them. In the recent past, public concern regarding the build up of pesticides in the environment has grown rapidly (Pedigo, 1996).

In addition to the increasing concern about environmental and health effects, other disadvantages of heavy dependence of chemical pesticides have become apparent. First, the price of synthetic organic pesticides and the cost of their application have risen significantly in recent years, placing a financial burden on those farmers and others who use large quantities of pesticides to control serious pests (Pedigo, 1996). Second, strains of pests have developed that are genetically resistant to pesticides. Moreover, secondary pest outbreaks that did not cause economic damage previously occur because of the continuing use of the chemical pesticides. In addition, destruction of natural control agents and pollinators has been observed to cause crop damage (Pedigo, 1996). The role of the university extension service in educating farmers about how to deal with pest problems is a key to better management (Seevers et al., 1995).

Statement of the Problem

The U.S. Department of Agriculture's (USDA) Integrated Pest Management (IPM) initiative established a goal of implementing IPM on $75 \%$ of 
the U.S. crop lands by the year 2000. USDA charged state Extension IPM coordinators with the tasks of promoting and measuring IPM adoption of agricultural producers and practitioners in an attempt to reach this goal (Alston and Reading, 1998).

Since 1978, annual reports have been submitted to the federal government related to integrated pest management programming in alfalfa, corn, apples and peaches in West Virginia. These reports are available, according to Dr. John F. Baniecki (2001), in the office of the Extension Specialist, Plant Pathology and Entomology, West Virginia University. However, there is little information available indicating the current extent to which West Virginia farmers are using Integrated Pest Management (IPM) and other pest control practices on farms. Such information is essential in order for the West Virginia Extension Service to plan programs that will benefit farm owners and overseers. In this context, the proposed research will gather pest management information by means of a survey from West Virginia corn growers.

\section{Purpose and Objective}

This study will provide information that might be useful to researchers and extension personnel at West Virginia University, Morgantown, WV in developing and designing educational programs concerning pest management for corn farmers. This research will identify current trends in management practices, insect, fungal, and weed problems, and educational needs so that instructional materials can be designed to meet clientele needs. 
Specific objectives of the study are:

1. To determine pest management practices used in corn production by West Virginia farmers.

2. To determine the major sources of pest management information used by West Virginia corn growers.

3. To determine instructional needs of West Virginia corn growers. 


\section{Chapter II}

\section{REVIEW OF LITERATURE}

Corn or maize is the most widely grown crop in the world. It is called the "king" of crops, its production and value is greater than that of wheat, barley, oats, rye, rice, and buckwheat. Corn is a crop that has become dependent upon man for its continued existence. Strange as is it may seem, a crop that is at the mercy of man is also one that responds most to the favors given by man. Corn is the most palatable of the cereal grains with low fiber content yet high in carbohydrates and oils. Both grain and fodder are valuable corn commodities, grain for human and animal consumption and fodder for animals. Besides being an important source of grain in livestock feeding, corn is also used as a source of roughage or fodder (silage) for dairy and beef cattle (National Agriculture Statistical Service, 1996).

In West Virginia, the corn area harvested for grain was 35,500 acres in 1997. Corn is the number one grain crop of West Virginia with production estimated at 4.27 million tons. Corn silage was harvested from 27,642 acres and the average yield for silage corn was 17 tons per acre (USDA, 1998). Early agriculture development was confined to the small valleys, along areas bordering rivers and the Eastern Panhandle. As lumber and mineral industries developed, more hill land was brought into cultivation, mostly in corn and small grains. Later, changes in mineral industries caused decreases in rural population. Associated with this decrease were declines in crop area cultivated and a shift to livestock farming. Hay began to replace grain crops. There were about 10.7 million acres 
of land in farms in the early 1900, decreasing steadily to 3.7 million in 1997. Based on the 1997 cash receipts of over $\$ 393$ million, the top ten commodities were: broilers, 35 percent; cattle and calves, 18 percent; dairy products, 9 percent; eggs, 6 percent; greenhouse and nursery, 4 percent; hay, 3 percent; apples, 3 percent; corn, 2 percent; and peaches, 1 percent (Baniecki and Dabaan, 1998).

The biggest problem in crop production is the damage caused by the insect pests. Northern corn rootworm and European corn borer cause the major damage to field corn in the North Central Corn Belt (Pedigo, 1996). One way to control this problem is by adopting integrated pest management practices. According to Pedigo, (1996, p. 648) “...Integrated pest management (IPM) is the comprehensive approach to dealing with pests that strives to reduce pest status to tolerable levels by using methods that are effective, economically sound, and ecologically compatible; most often involving multiple tactics; usually practice of individuals and private enterprises". Cultural, physical, mechanical, biological and chemical management are different components of IPM. Cultural management is the purposeful manipulation of a cropping environment to reduce rates of pest increase and damage.

Educating farmers to adopt these practices is very important and cooperative extension can play a vital role in such programs. The development of methods and materials that could be utilized for communicating new farming practices and various ways for controlling pests more effectively has been the result of the longstanding and closely-knit interrelationship of the agriculture 
system created by the Hatch Act (1887) and the Smith-Lever Act (1914). According to these Acts, Cooperative Extension is the major educational provider in adult and continuing education, particularly for agricultural audiences (Seevers et al., 1995). According to Smith (1972, p. 58), “...Cooperative extension is the educational partnership between the United States Department of Agriculture (USDA), the Land-grant University, and local community (the county). The system provides for program and financial resources from the USDA and the university, with programs being conducted at county level. In most states, local financial support and program direction is also provided. They have cultivated the capacity to be on the wavelength of the research scientists on the one hand and the producer on the other. It was the agent who was able to provide educational techniques for gaining almost immediate acceptance of recommendations developed from research findings.

Additionally, "...Extension is a major educational provider in adult and continuing education, particularly for agricultural audiences. The advent of computers and the information age has caused a knowledge explosion and created a continuing need for unbiased information available through extension education" (Trede and Whittaker, 1998).

The use of questionnaire technique has been successfully adopted by Long (1997) and Wilson (1990) who studied farm practices of corn growers from Washington and Ohio. Similarly, Alston (1998) studied IPM practices on tree fruit and small grain producers in Utah. In West Virginia, studies on pesticide usage 
have been researched on apples, alfalfa, sweet corn, and tobacco by Baniecki (1997). 


\section{Chapter III}

\section{RESEARCH METHODS AND PROCEDURES}

Data for this research study were obtained through a survey of farmers in the top ten corn producing counties in West Virginia. Information was secured by mailing the questionnaires to county Extension faculty who identified outstanding farmers to forward the questionnaire to. This study investigated the specific pest problems, management practices, and education needs of West Virginia corn growers.

This study was limited to farmers who produced corn in West Virginia during the 1999 crop year. In addition, ten county Agriculture Extension agents were asked to identify 10 outstanding corn growers from each of their respective counties. The word outstanding could have been interpreted in many ways. The agents may have chosen corn growers on the basis of who would actually follow through and fill out the survey or may have chosen farmers who had the highest yields in past years.

Small alfalfa growers in West Virginia do not have enough income to spend time on using IPM practices whereas the larger growers will spend the time and money to increase profit (Baniecki, 1999). Thus, agents were asked to choose the top ten corn growers in their county.

\section{Design}

The survey structure in this study is based on the model adapted on corn, and tree fruits and small grains (Long, 1997; Alston, 1998). Descriptive survey research method was used to collect data from corn growers from the top ten 
producing counties in West Virginia. Survey research is an appropriate mode of inquiry whenever it makes good sense to conceptualize what is being studied as essentially a distinct population of basically similar objects (Simmons and McCall, 1985, p. 119-120). The basic aims of survey research are in fact to statistically describe and explain the variability of certain features among those objects comprising some population.

\section{Population and Sample}

The population for this study was outstanding corn growers as of June 1 , of 1999 in West Virginia. Using the best estimates of West Virginia University Agricultural Specialists, the total population was determined to be $N=1500$. The purposeful sample size was determined to be 100 . Ten counties were chosen according to the amount of corn production occurring in 1997. Each of these 10 counties received 10 surveys, for a total of 100 surveys.

$\underline{\text { Instrumentation }}$

Mail questionnaires can be used to collect large amounts of information at a low cost per respondent. No interviewer is involved to bias the respondent's answers. However, mail questionnaires also have some disadvantages. They are not flexible, require simple and clearly worded questions; all respondents answer the same questions in a fixed order; and the researcher cannot adapt the questionnaire based on earlier answers. Mail surveys usually take longer to complete, and the response rate, the number of people returning completed questionnaires, is often very low. (Kotler and Armstrong, 1991, p. 103).

Accordingly, a well-designed questionnaire instrument (Appendix C) was mailed to corn growers via county extension agents to obtain the necessary information to meet study objectives. 
The survey form consisted of four parts. Part one of the survey inquired about pest problems (e.g., crop diseases, weeds, insect/mites, and vertebrates). Part two of the survey requested respondents to indicate the intensity of various control measures (e.g., chemical, cultural and biological) used during the past season. Part three of the survey inquired about the sources of information farmers use to assist in managing pest problems and which management practices they would like to receive more information on. Finally, part fourrequested demographic information such as acreage of corn grown and county where corn is farmed. A cover letter (Appendix B) explained the purpose of the study and gave directions for completing and returning the questionnaire. The researcher and committee chairman signed the cover letter. An addressed stamped envelope was included to help encourage the prompt return of the instrument.

Administration of the Instrument

Packets of ten copies of the questionnaire (Appendix C) accompanied by a letter of introduction (Appendix B) signed by graduate student and chairman of the research study committee, were sent to each of the ten county Extension agents. The first part elicited responses on pest problems; part two elicited responses to determine control measures used; part three sought educational needs of growers; and part four consisted of questions about demographics. A self-addressed stamped envelope was enclosed to encourage feedback.

In a letter (Appendix A), Extension agents were asked to choose ten outstanding corn growers in their county and to forward the survey to them. Each 
packet contained 10 postage-paid envelopes, each containing a survey, a return envelope and a cover letter.

Since the Extension agents selected the corn growers, the names of the participants were not disclosed to the researcher. Therefore, follow-up letters or post cards were not sent to any of the participants or prospective participants. The deadline for responding to the questionnaire was June 30, 1999. Thirty-three of the $100(33 \%)$ corn growers had returned their questionnaires by this date.

\section{Data Analysis}

This study sought to determine pest management practices, sources of educational information and instructional needs of West Virginia Corn growers. Frequencies, percentages and means were used to describe and analyze the data.

\section{Scope of Findings}

Findings from this study may be used by the West Virginia University Extension Service in further development of state wide educational workshops and outreaches for corn growers. Findings may also be used by county Agricultural Agents in development of county wide educational programs, which may increase the use of various management practices. 


\section{Chapter IV}

\section{RESULTS AND DISCUSSION}

The purpose of this study was to provide information to the West Virginia University Extension Service that may be useful in developing educational strategies aimed at increasing the knowledge and production output of corn growers in West Virginia. To accomplish this purpose, a sample of 100 corn growers were surveyed for their perceptions of pest management practices, sources of information and educational needs. The aggregate response rate from this sample was $33 \%(n=33)$.

Objectives of the study were:

1. To determine pest management practices currently used in corn production by West Virginia farmers.

2. To determine the major sources of pest management information used by West Virginia corn growers.

3. To determine instructional needs of West Virginia corn growers. Responses of West Virginia corn growers are summarized and results of the data analysis are presented in the following areas: Demographics of participants, severity of problems caused by crop diseases, severity of problems caused by weed pests, severity of problems caused by arthropods, severity of problems caused by vertebrates, selected control measures, and selected sources of educational material for managing pest problems. Data obtained from this study were analyzed by frequencies, percentages and means. 
The population of West Virginia corn growers studied consisted of outstanding corn growers as of June 1, 1999. Their local Extension agents selected participants for the study. Each participant completing the instrument was able to indicate county and acreage of farm. Descriptive statistics for these variables are shown in Table 1.

Two counties, "Berkeley and Randolph," did not have any respondents, which could have occurred for several reasons such as Extension agents not receiving their package, agents not sending the survey forms, and the participants choosing not to respond. Jefferson, Mason, and Hardy counties had the largest number of responses with six out of ten surveys being returned. Incidentally, these three counties had the largest acreage of corn production per farm. In summary, the farmers who had large acreages of corn production responded at a higher rate than those with smaller acreages. 
Table 1

Participants of the West Virginia Corn Growers Pest Management Survey: Number of Respondents and Acreage of Corn Production

\begin{tabular}{llll}
\hline County & \multicolumn{2}{l}{ Responses } & Average Acres/ Farm \\
\cline { 2 - 3 } Bumber & Percent & \\
Hampshire & 5 & 0 & 0 \\
Hardy & 5 & 15 & 27.4 \\
Jackson & 6 & 18 & 259 \\
Jefferson & 2 & 6 & 34 \\
Mason & 6 & 18 & 501 \\
Monroe & 6 & 18 & 342 \\
Pendleton & 3 & 9 & 60 \\
Preston & 2 & 6 & 20 \\
Randolph & 3 & 9 & 96 \\
\hline
\end{tabular}

Results of the problems caused by corn crop diseases in the year 1999 in West Virginia are shown in Table 2. Participants rated the problems on a scale of one to four $[1=$ not a problem, $2=$ low (injury occurs infrequently), $3=$ Moderate (injury occurs most years when crop is grown or level of injury may not require control), $4=$ severe (injury occurs whenever crop is grown if not controlled)]. Percentages in each table reflect the number of farmers responding to each item, which varies from 27 to 33 . 
Table 2

Severity of Diseases Perceived by West Virginia Corn Growers in 1999 ( $n=33)$

\begin{tabular}{|c|c|c|c|c|c|c|c|c|}
\hline \multirow[t]{2}{*}{ Pest Categories } & \multicolumn{2}{|c|}{$\begin{array}{c}\text { Not a } \\
\text { problem }\end{array}$} & \multicolumn{2}{|c|}{$\begin{array}{c}\text { Low } \\
\text { (Injury occurs } \\
\text { Infrequently) }\end{array}$} & \multicolumn{2}{|c|}{$\begin{array}{c}\text { Moderate } \\
\text { (Injury occurs most } \\
\text { years when crop is } \\
\text { grown) }\end{array}$} & \multicolumn{2}{|c|}{$\begin{array}{c}\text { Severe } \\
\text { (Injury occurs } \\
\text { whenever crop is } \\
\text { grown) }\end{array}$} \\
\hline & No. & $\%$ & No. & $\%$ & No. & $\%$ & No. & $\%$ \\
\hline$\overline{\text { Ear rot }}$ & 20 & 69 & 9 & 31 & 0 & 0 & 0 & 0 \\
\hline Corn smut & 18 & 60 & 11 & 37 & 1 & 3 & 0 & 0 \\
\hline Stalk rot & 11 & 38 & 12 & 41 & 6 & 21 & 0 & 0 \\
\hline Bacterial wilt & 19 & 63 & 9 & 30 & 2 & 7 & 0 & 0 \\
\hline Gray leaf spot & 7 & 23 & 11 & 36 & 6 & 20 & 6 & 20 \\
\hline Leaf blight & 9 & 30 & 15 & 50 & 6 & 20 & 0 & 0 \\
\hline Maize virus & 14 & 43 & 5 & 15 & 11 & 33 & 3 & 9 \\
\hline Rust & 19 & 68 & 8 & 29 & 1 & 3 & 0 & 0 \\
\hline Seed rot & 17 & 57 & 12 & 40 & 1 & 3 & 0 & 0 \\
\hline Seedling blight & 18 & 67 & 9 & 33 & 0 & 0 & 0 & 0 \\
\hline $\begin{array}{l}\text { Northern corn leaf } \\
\text { blight }\end{array}$ & 15 & 50 & 10 & 33 & 5 & 17 & 0 & 0 \\
\hline
\end{tabular}

The percentages reported reflect the number who responded regarding each disease

Gray leaf spot (20\%) and Maize virus (9\%) are the two diseases reported to have caused severe injury. Five other diseases show moderate injury (injury occurs most years when crop is grown: Maize virus (33\%), Stalk rot $(21 \%)$, Leaf blight (20\%), Gray leaf spot (20\%), and Northern corn leaf blight (17\%). Ear rot and Seedling blight are the only two diseases that did not cause moderate or severe problems.

Problems caused by corn weed pests in 1999 in West Virginia are shown in Table 3. Participants rated the problems on a scale of one to four $[1=$ not a 
problem, $2=$ low (injury occurs infrequently), $3=$ Moderate (injury occurs most years when crop is grown or level of injury may not require control), $4=$ severe (injury occurs whenever crop is grown if not controlled)].

Table 3

Severity of Problems Caused by Weed Pests Perceived by West Virginia Corn Growers in $1999(n=33)$

\begin{tabular}{lllllllll}
\hline Pest Categories & \multicolumn{2}{l}{$\begin{array}{l}\text { Not a } \\
\text { problem }\end{array}$} & $\begin{array}{l}\text { Low } \\
\text { (Injury occurs } \\
\text { Infrequently) }\end{array}$ & $\begin{array}{l}\text { Moderate } \\
\text { (Injury occurs most } \\
\text { years when crop is } \\
\text { grown) }\end{array}$ & $\begin{array}{l}\text { Severe } \\
\text { (Injury occurs } \\
\text { whenever crop is } \\
\text { grown) }\end{array}$ \\
& No. & $\%$ & No. & $\%$ & No. & $\%$ & No. & $\%$ \\
\hline Wild oats & 26 & 81 & 5 & 16 & 0 & 0 & 1 & 3 \\
Quack grass & 11 & 35 & 15 & 48 & 4 & 13 & 1 & 3 \\
Pigweed & 8 & 24 & 8 & 24 & 7 & 21 & 10 & 30 \\
Velvet leaf & 9 & 28 & 11 & 34 & 8 & 24 & 4 & 13 \\
Kochia & 26 & 84 & 4 & 13 & 1 & 3 & 0 & 0 \\
Bindweed & 20 & 65 & 9 & 29 & 2 & 6 & 0 & 0 \\
Johnson grass & 8 & 25 & 4 & 13 & 7 & 22 & 13 & 40 \\
Fall panicum & 5 & 16 & 8 & 26 & 11 & 35 & 7 & 23 \\
Foxtail & 6 & 19 & 13 & 40 & 7 & 22 & 6 & 19 \\
Ragweed & 11 & 34 & 9 & 28 & 7 & 22 & 5 & 16 \\
Lambsquater & 0 & 0 & 0 & 0 & 1 & 17 & 5 & 83 \\
\hline
\end{tabular}

The percentages reported reflect the number who responded regarding each weed.

Johnson grass (40\%) and Pigweed (30\%) showed the highest responses in the severe category for weed pests. In fact, more than half the respondents rated these two pests as moderate or severe problems, $62 \%$ and $51 \%$ respectively, and $58 \%$ rated Fall Panicum similarly. Foxtail (41\%), Ragweed 
$(38 \%)$, and Velvet leaf $(37 \%)$ rated as moderate or severe problems as well. Rated as not a problem or low problems were Kochia (97\%), Wild oats $(97 \%)$, Bindweed (94\%), Quack grass (83\%).

Similarly participants were asked to rate perceived problems caused by corn insect and mite pests in the year 1999 (Table 4). Participants rated the problems on a scale of one to four $[1=$ not a problem, $2=$ low (injury occurs infrequently), $3=$ Moderate (injury occurs most years when crop is grown or level of injury may not require control), $4=$ severe (injury occurs whenever crop is grown if not controlled)]. 
Table 4

Severity of Arthropod Problems reported by West Virginia Corn Growers in 1999 $\underline{(n=33)}$

\begin{tabular}{|c|c|c|c|c|c|c|c|c|}
\hline \multirow[t]{2}{*}{ Pest Categories } & \multicolumn{2}{|c|}{$\begin{array}{l}\text { Not a } \\
\text { problem }\end{array}$} & \multicolumn{2}{|c|}{$\begin{array}{l}\text { Low } \\
\text { (Injury occurs } \\
\text { Infrequently) }\end{array}$} & \multicolumn{2}{|c|}{$\begin{array}{l}\text { Moderate } \\
\text { (Injury occurs most } \\
\text { years when crop is } \\
\text { grown) }\end{array}$} & \multicolumn{2}{|c|}{$\begin{array}{l}\text { Severe } \\
\text { (Injury occurs when- } \\
\text { ever crop is grown) }\end{array}$} \\
\hline & No. & $\%$ & No. & $\%$ & No. & $\%$ & No. & $\%$ \\
\hline Corn leaf aphids & 24 & 83 & 4 & 14 & 1 & 3 & 0 & 0 \\
\hline Corn Earworm & 10 & 36 & 12 & 43 & 6 & 21 & 0 & 0 \\
\hline Corn Rootworm & 11 & 36 & 8 & 27 & 8 & 27 & 3 & 10 \\
\hline Cutworms & 10 & 33 & 11 & 37 & 5 & 17 & 4 & 13 \\
\hline Armyworms & 11 & 37 & 11 & 36 & 6 & 20 & 2 & 7 \\
\hline European Corn borer & 5 & 16 & 11 & 35 & 11 & 35 & 4 & 13 \\
\hline Common Stalk borer & 9 & 29 & 10 & 32 & 12 & 39 & 0 & 0 \\
\hline Corn sap beetle & 24 & 86 & 4 & 14 & 0 & 0 & 0 & 0 \\
\hline Grasshoppers & 23 & 77 & 7 & 23 & 0 & 0 & 0 & 0 \\
\hline Seed corn maggot & 17 & 57 & 11 & 36 & 2 & 7 & 0 & 0 \\
\hline Slugs & 12 & 40 & 9 & 30 & 8 & 27 & 1 & 3 \\
\hline Wireworms & 15 & 48 & 11 & 35 & 4 & 13 & 1 & 3 \\
\hline Japanese beetle & 16 & 55 & 9 & 31 & 4 & 14 & 0 & 0 \\
\hline Corn flea beetle & 18 & 60 & 10 & 33 & 2 & 7 & 0 & 0 \\
\hline
\end{tabular}

The percentages reported reflect the number who responded regarding each pest

According to the West Virginia corn growers, only five arthropod pests caused severe problems in 1999. Problems associated with Cutworms and European corn borer were perceived to be severe by $13 \%$ of the respondents, followed by Corn rootworm (10\%), Army worms (7\%), and Slugs and Wireworms at $3 \%$. Rated as moderate or severe problems, however, were Corn borer $(48 \%)$, 
Common stalk borer (39\%), Corn root worm (37\%), Slugs (30\%), Army worms $(27 \%)$ and Corn earworm (21\%). Other arthropods were considered to cause low injury or were not a problem. Lepidopteran and coleopteran pests appear to be the major groups of insect pests of corn in West Virginia. According to Pedigo (1996), Northern corn rootworm and European corn borer cause the major damage to field corn in the North Central Corn Belt.

In this study, corn growers were also asked to rate their perceived problems caused by vertebrate pests in West Virginia (Table 5). Participants rated the problems on a scale of one to four $[1=$ not a problem, $2=$ low (injury occurs infrequently), $3=$ Moderate (injury occurs most years when crop is grown or level of injury may not require control), $4=$ severe (injury occurs whenever crop is grown if not controlled)].

Table 5

Corn Growers' Perception of the Severity of Problems Caused by Vertebrate Pests in West Virginia $(n=33)$

\begin{tabular}{|c|c|c|c|c|c|c|c|c|}
\hline \multirow[t]{2}{*}{$\begin{array}{l}\text { Vertebrate } \\
\text { Pests }\end{array}$} & \multicolumn{2}{|c|}{$\begin{array}{l}\text { Not a } \\
\text { problem }\end{array}$} & \multicolumn{2}{|c|}{$\begin{array}{l}\text { Low } \\
\text { (Injury occurs } \\
\text { Infrequently) }\end{array}$} & \multicolumn{2}{|c|}{$\begin{array}{l}\text { Moderate } \\
\text { (Injury occurs most } \\
\text { years when crop is } \\
\text { grown) }\end{array}$} & \multicolumn{2}{|c|}{$\begin{array}{l}\text { Severe } \\
\text { (Injury occurs } \\
\text { when- ever crop } \\
\text { is grown) }\end{array}$} \\
\hline & No. & $\%$ & No. & $\%$ & No. & $\%$ & No. & $\%$ \\
\hline Birds & 5 & 17 & 11 & 36 & 7 & 23 & 7 & 23 \\
\hline Rodent & 13 & 43 & 12 & 40 & 2 & 7 & 3 & 10 \\
\hline Deer & 3 & 9 & 3 & 9 & 8 & 24 & 19 & 58 \\
\hline Raccoons & 10 & 36 & 6 & 21 & 5 & 18 & 7 & 25 \\
\hline
\end{tabular}

Whenever corn is grown, deer was perceived as the most severe vertebrate pest of corn with $82 \%$ of the respondents rating deer damage as 
moderate or severe. Birds (46\%) and raccoons (43\%) also caused moderate or severe problems. Rodents caused the least amount of problems with $83 \%$ of the respondents rating damage as low or not a problem. 
Table 6

Selected Control Measures Used by West Virginia Corn Growers ( $n=33)$

\begin{tabular}{|c|c|c|c|c|c|c|c|c|}
\hline \multirow[t]{2}{*}{ West Virginia } & \multicolumn{2}{|c|}{ Do not use } & \multicolumn{2}{|c|}{$\begin{array}{l}\text { Low } \\
\text { (1 time per } \\
\text { season) }\end{array}$} & \multicolumn{2}{|c|}{$\begin{array}{l}\text { Moderate } \\
\text { ( } 2 \text { times per } \\
\text { season) }\end{array}$} & \multicolumn{2}{|c|}{$\begin{array}{l}\text { High } \\
\text { ( } 3 \text { times or } \\
\text { more per } \\
\text { season) }\end{array}$} \\
\hline & No. & $\%$ & No. & $\%$ & No. & $\%$ & No. & $\%$ \\
\hline $\begin{array}{l}\text { Field inspection, e.g. sampling for } \\
\text { pest and beneficial insects }\end{array}$ & 1 & 3 & 10 & 36 & 8 & 29 & 9 & 32 \\
\hline $\begin{array}{l}\text { Temperature based model to help } \\
\text { determine timing for pest control, e.g. } \\
\text { degree-days }\end{array}$ & 22 & 79 & 4 & 14 & 2 & 7 & 0 & 0 \\
\hline $\begin{array}{l}\text { Insecticide applications for control of } \\
\text { insects }\end{array}$ & 6 & 21 & 13 & 47 & 5 & 18 & 4 & 14 \\
\hline $\begin{array}{l}\text { Seed treatments for control of insects } \\
\text { and fungi }\end{array}$ & 4 & 13 & 18 & 58 & 5 & 16 & 4 & 13 \\
\hline $\begin{array}{l}\text { Fungicide applications to control } \\
\text { fungal diseases }\end{array}$ & 19 & 68 & 8 & 29 & 0 & 0 & 1 & 3 \\
\hline $\begin{array}{l}\text { Herbicide applications for control of } \\
\text { weeds }\end{array}$ & 1 & 3 & 9 & 28 & 18 & 56 & 4 & 13 \\
\hline $\begin{array}{l}\text { Selection of varieties resistant to } \\
\text { insect and diseases }\end{array}$ & 4 & 14 & 9 & 32 & 9 & 32 & 6 & 22 \\
\hline $\begin{array}{l}\text { Pest thresholds to assist with } \\
\text { determining when a pest is of } \\
\text { economic concern }\end{array}$ & 9 & 33 & 8 & 30 & 3 & 11 & 7 & 26 \\
\hline Cultivation for control of weeds & 22 & 76 & 6 & 21 & 0 & 0 & 1 & 4 \\
\hline $\begin{array}{l}\text { Spot chemical treatments for hotspot } \\
\text { outbreaks }\end{array}$ & 8 & 27 & 16 & 53 & 4 & 13 & 2 & 7 \\
\hline $\begin{array}{l}\text { Sanitation practices, e.g. cultivation } \\
\text { and removal of plant debris }\end{array}$ & 15 & 54 & 9 & 32 & 3 & 11 & 1 & 4 \\
\hline $\begin{array}{l}\text { Plant ground covers for enhancing } \\
\text { beneficial insects }\end{array}$ & 17 & 63 & 6 & 22 & 0 & 0 & 4 & 15 \\
\hline $\begin{array}{l}\text { Reduced chemical rates to preserve } \\
\text { beneficial insects }\end{array}$ & 13 & 43 & 13 & 43 & 2 & 7 & 2 & 7 \\
\hline $\begin{array}{l}\text { Release of biological control agents } \\
\text { (ladybeetles, Parasitic wasps, etc) }\end{array}$ & 25 & 86 & 2 & 7 & 0 & 0 & 2 & 7 \\
\hline $\begin{array}{l}\text { Selection of transgenic varieties of } \\
\text { corn (bt) and Round-up ready corn }\end{array}$ & 18 & 62 & 2 & 7 & 4 & 14 & 5 & 17 \\
\hline
\end{tabular}

Percentages reported reflect the number who responded to each item listed. 
Table 6 shows selected control measures for pest problems on corn grown in West Virginia in the 1999 growing season. As stated earlier, participants rated the problems on a scale of one to four $(1=$ do not use, $2=$ use one time per season, $3=$ use two times per season, $4=$ uses three times or more per season).

Among the numerous types of control measures, West Virginia corn growers indicated the following measures least likely to be used: release of biological control agents (ladybird beetles, parasitic wasps, etc) at $86 \%$, temperature based model (degree-days) to help determine timing for pest control (79\%), cultivation for control of weeds at $76 \%$, fungicide applications to control fungal diseases at $68 \%$, plant ground covers for enhancing beneficial insects at $63 \%$, and transgenic varieties of corn (bt) and Round-up ready corn at $62 \%$. Control measures used one time per season by a majority of respondents were as follows: $58 \%$ used seed treatments for control of insects and fungi and $53 \%$ used spot chemical treatments for hotspot outbreaks. Used two or more times during the season were herbicide applications for control of weeds (69\%), field inspection (61\%), and selection of varieties resistant to insect and diseases $(54 \%)$. 
Table 7

Sources of Information Regarding Pest Problems Used by West Virginia Corn Growers $(n=33)$

\begin{tabular}{|c|c|c|c|c|c|c|c|c|}
\hline \multirow[t]{2}{*}{ Source } & \multicolumn{2}{|c|}{ Do not use } & \multicolumn{2}{|c|}{ Low use } & \multicolumn{2}{|c|}{ Moderate use } & \multicolumn{2}{|c|}{ High use } \\
\hline & No. & $\%$ & No. & $\%$ & No. & $\%$ & No. & $\%$ \\
\hline Agri. chemical dealers/representative & 0 & 0 & 2 & 6 & 14 & 41 & 18 & 53 \\
\hline Private crop /pest consultant & 16 & 57 & 6 & 21 & 3 & 11 & 3 & 11 \\
\hline County Extension agent/office & 6 & 19 & 7 & 22 & 15 & 47 & 4 & 12 \\
\hline University specialist & 7 & 24 & 14 & 48 & 8 & 28 & 0 & 0 \\
\hline Other growers & 4 & 13 & 9 & 30 & 10 & 33 & 7 & 23 \\
\hline State department of Agriculture & 19 & 63 & 8 & 27 & 3 & 10 & 0 & 0 \\
\hline Use of internet to research problem & 22 & 73 & 3 & 10 & 4 & 13 & 1 & 3 \\
\hline Farm magazine/trade journals & 2 & 6 & 6 & 19 & 18 & 58 & 5 & 16 \\
\hline Workshop and conferences & 7 & 25 & 10 & 35 & 8 & 29 & 3 & 11 \\
\hline Radio programs & 22 & 76 & 2 & 6 & 4 & 14 & 1 & 4 \\
\hline Television programs & 22 & 73 & 4 & 13 & 2 & 7 & 2 & 7 \\
\hline Agriculture teacher & 22 & 79 & 4 & 14 & 2 & 7 & 0 & 0 \\
\hline Pesticide update training & 9 & 29 & 3 & 10 & 12 & 39 & 7 & 22 \\
\hline Newspaper & 19 & 68 & 4 & 14 & 3 & 11 & 2 & 7 \\
\hline
\end{tabular}

Percentages reflect the number who responded to each item listed.

Participants were asked to indicate where they obtained information to make decisions on pest management problems for corn (Table 7). Participants rated the sources on a scale of one to four $(1=$ do not use, $2=$ low use, $3=$ moderate use, $4=$ high use).

Moderate and high uses were made of agricultural chemical dealers/representatives $(94 \%)$, farm magazines $(74 \%)$, pesticide update training 
(61\%), county extension agent/office (59\%), other growers (56\%), workshops and conferences (40\%), university specialists (28\%), private crop/pest consultant $(22 \%)$, radio programs $(18 \%)$, newspaper $(18 \%)$, television programs $(14 \%)$, internet (13\%), State Department of Agriculture (10\%), and agriculture teachers $(7 \%)$.

Lastly, participants were asked to indicate, using a check mark, items on which they would like to have more information. These data are found in Table 9. More than $25 \%$ of the respondents indicated additional information would be welcome concerning selection of transgenic varieties of corn (bt) and Round-up ready corn (42\%), ground covers for enhancing beneficial insects $(33 \%)$, biological control agents (30\%), and field inspection techniques (27\%). 
Table 8

Informational Needs of West Virginia Corn Growers $(n=33)$

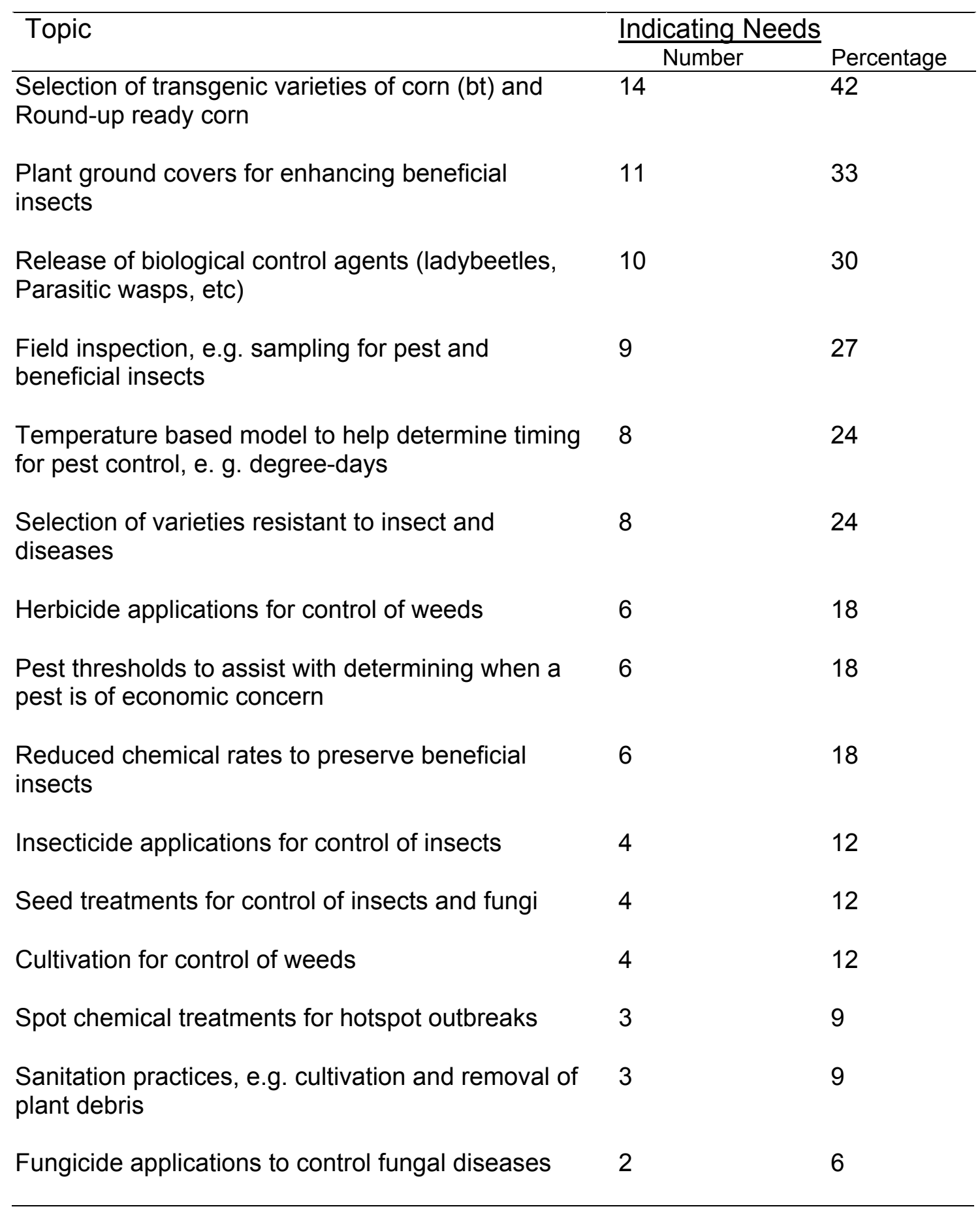




\section{Chapter V}

\section{SUMMARY, CONCLUSIONS AND RECOMMENDATIONS}

\section{Summary}

The purpose of this study was to provide information to the WVU Extension personnel and researchers that may be useful in developing and designing educational programs concerning pest management practices, insect, fungal, and weed problems, and educational needs so that instructional material can be designed to meet clientele needs. The objectives of this study were:

1. To determine current pest management practices used in corn production by West Virginia farmers.

2. To determine the major sources of pest management information used by West Virginia corn growers.

3. To determine instructional needs of West Virginia corn growers.

Data were collected via $33 \%$ of the 100 surveys mailed to outstanding corn growers in West Virginia during 1999 crop season for a 33\% response rate. Packets of 10 surveys were sent to Agriculture Extension agents in the top ten corn-growing counties. These agents in turn chose ten outstanding growers in their county; the surveys were then mailed to these corn growers. Thirty-three useable surveys were returned and provided data for the study.

The survey form consisted of four parts. Part one of the survey inquired about pest problems (crop diseases, weeds, insect/mites, and vertebrates). Part two requested respondents to indicate the intensity of various control measures (chemical, cultural and biological) used during the past season. Part three 
inquired about the sources of information farmers use to assist in managing pest problems. Finally, part four-requested acreage of corn grown and county where corn is farmed. A cover letter explained the purpose of the study and gave directions for completing and returning the questionnaire. The researcher and committee chairman signed the cover letter. A self-addressed stamped envelope was included to help encourage the prompt return of the instrument.

Characteristics of the 33 respondents were as follows. Fifty-four percent of the growers had acreage of 259 acres or more, $18 \%$ of the growers had acreages of 60 to 96 acres, and $27 \%$ of growers had 34 acres or less.

Growers were asked to rate their perceived severity of injury caused by crop diseases. Participants were encouraged to rate all diseases that applied. Gray leaf spot, maize virus, stalk rot, leaf blight, and northern corn leaf blight were the diseases indicated by growers to cause moderate to severe damage in the 1999 growing season.

Participants were asked to rate their perceived severity of injury caused by weed pests. Among all weeds listed three weeds stood out with more than half of the respondents indicating severe or moderate injury. These weeds were johnson grass, pigweed, and fall panicum.

Similarly participants were asked to rate perceived injury caused by insect pests and mites for corn. Lepidopteron and coleopteran pests appear to be the major groups of insect pests of corn in West Virginia. Arthropods which were noted as causing severe or moderate injury were cutworms, european corn 
borer, army worms, slugs, wireworms, common stalk borer, corn root worm, and corn earworm.

In this study, corn growers were also asked to rate the perceived injury caused by vertebrate pests. Deer were perceived as the most severe pest of corn with $82 \%$ of the respondents rating deer damage as moderate or severe. Birds and raccoons were rated $46 \%$ and $43 \%$, respectively.

Participants were asked to rate control measures used in the 1999 corngrowing season. The most common control measures were applications of herbicide to control weeds, field inspection, and selection of varieties resistant to insect and diseases.

Participants were asked to indicate where they obtained their information to make decisions on pest management for corn. Agricultural chemical dealers/representatives, farm magazines, pesticide update training, county extension agent/office, and other growers were the six sources that received moderate or higher use ratings as information sources.

More than $25 \%$ of the growers indicated need for additional information concerning transgenic corn varieties, ground covers for enhancing beneficial insects, biological control agents, and field inspection techniques.

\section{$\underline{\text { Conclusions }}$}

Based on West Virginia data obtained through this study the following conclusions were reached:

1. The most severe losses in corn due to diseases result from maize virus, gray leaf spot, stalk rot, leaf blight and northern corn leaf blight. 
2. Weed pests causing the greatest injury to corn are johnson grass, pigweed and fall panicum.

3. Insect and mite pests causing the greatest damage to corn are european corn borer, common stalk borer, corn rootworm, slugs, armyworms and corn earworm.

4. Deer are, by far, the most injurious vertebrate pest of corn in West Virginia. Birds and raccoons also cause considerable damage.

5. Pest control measures most often used by West Virginia corn growers are herbicide applications field inspections and selection of varieties resistant to insects and diseases.

6. West Virginia corn growers receive information regarding pest problems and control measures from a number of sources including Agriculture chemical dealers/representatives, farm magazines, pesticide update training, extension agents, other growers, workshops, and university specialists.

7. Corn growers would like to receive additional information regarding transgenic varieties, ground covers that enhance beneficial insect population, biological control agents, field inspection procedures, temperature based models, and variety selection.

\section{$\underline{\text { Recommendations }}$}

1. Results of this survey should be made available to West Virginia University researchers and extension specialists. 
2. Best Management Practices (BMP) should be developed for corn production in West Virginia and made available to producers through workshops, printed materials and the internet.

3. It should be determined if additional research is needed to develop control measures for insect, weed, disease and vertebrate pests causing severe damage to corn grown in the state. 


\section{BIBLIOGRAPHY}

Alston, D. G. and Reading, M. E. (1998). Factors influencing adoption and educational outreach of Integrated Pest Management. Journal of Extension. 36(3). Available at http://www.joe.org/joe/1998june/a3.html.

Baniecki, J. F. (1999). Personal interview on May 14.

Baniecki, J. F. (2001). Personal correspondence, August 15.

Baniecki, J. F. and Culik, M. P. (1997). Usage of newer pesticides by apples, alfalfa, and tobacco growers. Extension Service, Morgantown: West Virginia University.

Baniecki, J. F. and Dabaan, M. E. (1998). Agriculture in the mountain state. Prepared by the West Virginia Agriculture Statistics Service. Available at http://www.wvu.edu/ agexten/ipm/pestprog/NAIPAP/agricult.htm.

Flint, M. L. and Van den Bosch, R. (1981). Introduction to integrated pest management. New York: Plenum Press.

Kotler, P. and Armstrong, G. (1991). Principles of marketing ( $5^{\text {th }}$ edition). New Jersey: Prentice-Hall, Inc.

Lackey, J. (No date). Corn as a crop, Aphis, USDA. Available at http://www.aphis.usda.gov/BBEP/BP/corn.html.

Long, G. and Callentiine, B. (1996). Washington corn IPM survey. Washington State University. Available at http://cru44.cahe.wsu.edu/surveys/corn.html.

Magness, J. R., Markle, G. M. and Compton, C. C. (1971). Food and feed crops of the United States. Interregional Research Project IR-4, IR Bul. 1 (Bul. 828 New Jersey Agriculture Experiment Station).

National Agriculture Statistical Service, World agricultural supply and demand estimates 1996. USDA Economics and Statistics System, Albert R. Mann Library, Cornell University. Available at: http://usda.mannlib.cornell.edu/reports/waobr/wasde-bb/1996/wasde_01.16.96.

Pedigo, L. (1996) Entomology and pest management (2nd edition), Upper Saddle River, NJ: Prentice Hall.

Seevers, B., Graham, D., Gamon, J., and Conklin, N. (1995). Education through cooperative extension. Albany, NY: Delmar Publishers.

Simmons, J. and McCall G. (1985). Social research: the craft of finding out. New York: Macmillan Publishing Company. 
Smith, E. H. (1972). Pest control strategies for the future agricultural board. National Academy of Sciences. Division of Biology and Agriculture. National Research Council, Washington, D. C., pp. 57 - 60.

Trede, L. D. and Whittaker, S. (1998). Beginning farmer education in lowa: implications to extension. Journal of Extension [online serial] 36(5). Available at http://www.joe.org/joe/1998october/a3.html.

United States Department of Agriculture, (1998). West Virginia 1997 census of agriculture. West Virginia Agriculture Statistics Annual Bulletin No. 23 (pg 8). Available at: http://www.nass.usda.gov/census/census97/highlights /wv/wv_fig5.gif.

Wilson, H. R. (1993). Field corn pest management. The Ohio State University Extension. Available at http://www.ag.ohio-state.edu/ ohioline/icmfact/icm-fact/fc-11html. 


\section{APPENDICES}




\section{APPENDIX A}

Letter to County Extension Agents 
June 4, 1999

\section{Extension Agent's Address}

\section{Dear [County Extension Agent]:}

As part of a thesis study in agriculture education at West Virginia University, we are surveying West Virginia corn growers to determine their current pest management practices, sources of pest management information, and education needs. To do this, we need your assistance.

In this package of ten postage-paid envelopes. Each on contains a survey and cover letter explaining the purpose of the study. A copy for you to review is attached. We are asking for your help in getting these survey forms to the corn producers in your county.

Please select ten outstanding producers in your county to participate in the study. Then address the envelopes to those farmers and mail them as quickly as possible. Results will be made available to you and your colleagues upon completion of the study.

Thank you in advance for your help. Your assistance is of utmost importance and we sincerely appreciate your time and effort

Sincerely,

Leasa Wilkerson Gudderra Graduate Student

Layle D. Lawrence

Professor, Agriculture Education

John F. Baniecki

Extension Specialist 
APPENDIX B

Cover letter to participants 
June 10,1999

\section{Dear West Virginia Corn Producer:}

We need your help! We are asking for your cooperation in a thesis study designed to determine current pest management, sources of pest management information, and educational needs of corn growers in West Virginia. We have asked your county Extension agent for assistance and you have been selected as one of ten outstanding growers in your county to participate in this study.

Enclosed is a survey form from the Agriculture education department at West Virginia University, which will require 10 minutes to complete. Of course, your participation is voluntary and any information you provide will remain confidential. Information obtained from the study will aid in development of educational materials and programs concerning pest management for corn growers.

When all surveys have been returned, information you provide will be combined with that of other growers throughout the State. Results will be available from you county Extension agent, or you may request a copy on the back page of the survey form.

Your participation, and return of the questionnaire by June 30, 1999, will be greatly appreciated. Please use the self-addressed, stamped envelope provided to return your survey.

Thank you so much for your assistance. Your participation will help West Virginia's Cooperative Extension Service provide useful information to all of the State's corn growers.

Sincerely,

Leasa Wilkerson Gudderra

Graduate Student

Layle D. Lawrence

Professor, Agriculture Education

cc: County Extension Faculty 
APPENDIX C

Questionnaire 


\section{WEST VIRGINIA CORN GROWERS PEST MANAGEMENT \\ 1999}

\section{A Survey of Pest Management Practices Used by West Virginia Corn Growers.}

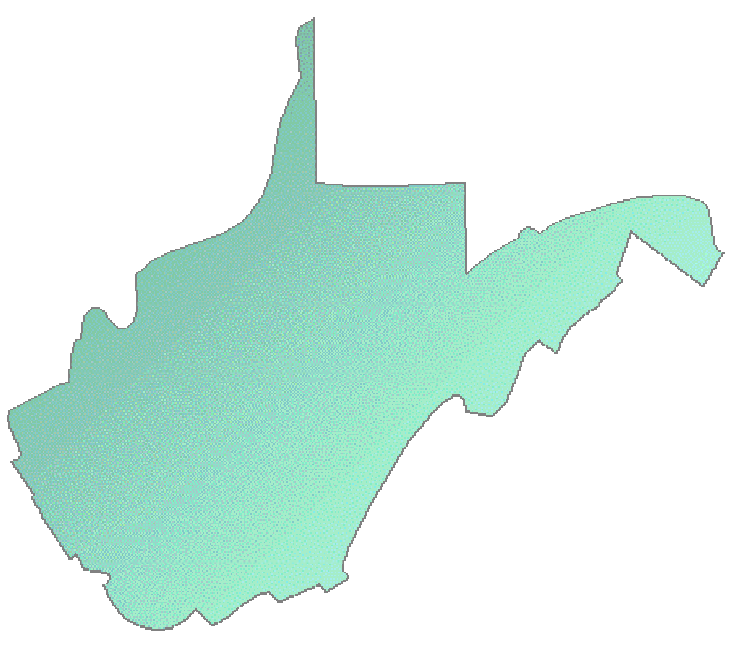

This statewide survey is an effort to identify the management practices of corn growers and what they perceive, as educational needs.

Your participation in this survey will help to identify the needs for research and educational activities. Please take a few minutes to complete it. Please return the survey in the selfaddressed postage paid envelope provided.

Please return this questionnaire to:

Leasa Wilkerson Gudderra

C/o Layle Lawrence

College of Agriculture and Resource Management

2056 Agriculture Science Building PO BOX 6108

Morgantown, West Virginia 26506-6108 


\section{Pest Management Survey for West Virginia Corn Growers}

\section{Section I. Pest Problems}

Please rate the pest problems in your fields.

Ratings for questions 1-4:

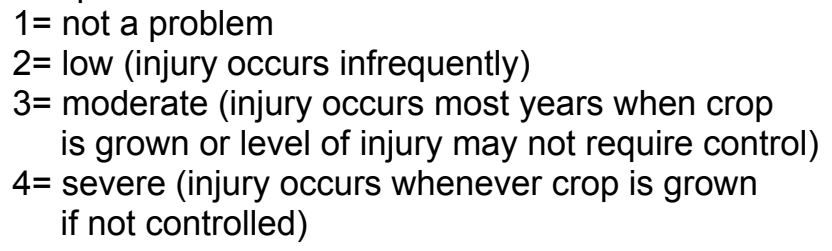

Circle the appropriate rating (1-4) for each pest.

1. Crop Diseases

\begin{tabular}{|c|c|}
\hline Ear rot & 1234 \\
\hline Corn smut & 1234 \\
\hline Stalk rot & 1234 \\
\hline Bacterial wilt & 1234 \\
\hline Gray leaf spot & 1234 \\
\hline Leaf blight & 1234 \\
\hline Maize virus & 1234 \\
\hline Rust & 1234 \\
\hline Seed rot & 1234 \\
\hline Seedling blight & 1234 \\
\hline Northern corn leaf blight & 1234 \\
\hline Other & 1234 \\
\hline
\end{tabular}

2. Weeds

Wild oats $\quad 1234$

Quackgrass 1234

Pigweed 1234

Velvet leaf 1234

Kochia 1234

Bindweed 1234

Johnson grass $\quad 1234$

Fall panicum 1234

Foxtail 1234

Ragweed 1234

Other_ 1234 
3. Insects/Mites

Corn leaf aphids 1234

Corn earworm 1234

Corn rootworm 1234

Cutworms 1234

Armyworms 1234

European corn borer $\quad 1234$

Common stalk borer 1234

Corn sap beetle 1234

Grasshoppers 1234

Seed corn maggot 1234

Slugs 1234

Wireworms 1234

Japanese beetle 1234

Corn flea beetle 1234

Other 1234

\section{Vertebrates}

Birds

Rodents

1234

Deer

Raccoons

1234

1234

Other

1234 


\section{Section II. Control Measures}

\section{Control Measures}

Please indicate all that apply and the intensity it is used.

Rating scale: $1=$ do not use

$2=$ low use ( 1 time per season)

$3=$ moderate use ( 2 times per season)

$4=$ high use ( 3 times or + per season)

Circle the rating (1-4) that best describes your use of each control measure (a- o).

(a) Field inspection, e.g. sampling for pest and beneficial insects

(b) Temperature based model to help determine timing for pest control, e.g. degree-days.

(c) Insecticide applications for control of insects

(d) Seed treatments for control of insects and fungi

1234

(e) Fungicide applications to control fungal diseases

1234

(f) Herbicide applications for control of weeds

1234

(g) Selection of varieties resistant to insect and diseases

(h) Pest thresholds to assist with determining when a pest is of economic concern.

(i) Cultivation for control of weeds

(j) Spot chemical treatments for hotspot outbreaks

(k) Sanitation practices, e.g. cultivation and removal of plant debris.

(I) Plant ground covers for enhancing beneficial insects

(m) Reduced chemical rates to preserve beneficial insects 1234

(n) Release of biological control agents (ladybeetles, Parasitic wasps, etc)

(o) Selection of transgenic varieties of corn (bt) and Round-up ready corn

(p) Other

6. Please check the letter of the practice from question $\mathbf{5}$ (Control Measures) that you would be interested in knowing more about.
a)
b)
c)
d)
e)
f)
g)
h)
I)
j)
K)
I)
m)
n)
) 


\section{Section III. Education}

7. Where do you obtain information to assist you with managing pest problems? Indicate all of the following that apply and rate by frequency that you use these resources.

Rating scale:

$$
\begin{aligned}
& 1=\text { do not use } \\
& 2=\text { low use } \\
& 3=\text { moderate use } \\
& 4=\text { high use }
\end{aligned}
$$

Circle the rating (1-4) that best describes your use of each resource.

Agri. chemical dealer/representative

Private crop/pest consultant

County Extension Service agent/office

University specialist

Other growers

State department of Agriculture

Use of Internet to research problem

Farm magazine/ trade journals

Workshops and conferences

Radio programs

Television programs

Agriculture teacher

Pesticide update training

Newspaper

Other
1234

1234

1234

1234

1234

1234

1234

1234

1234

1234

1234

1234

1234

1234

1234

\section{Section IV. General Farm Information:}

8. County where corn is farmed

9. How many acres do you have in corn? acres 
Thank you for answering these questions.

Please, fold this booklet and place it in the envelope provided. The survey results can only be used if we receive them in time.

In case, the return envelope is misplaced mail the survey to:

Leasa Wilkerson Gudderra

C/o Layle D. Lawrence

West Virginia University

College of Agriculture, Forestry and Consumer services

2056 Agriculture Sciences Building

Morgantown, West Virginia 26506-6108

Thank you for taking the time to complete the survey! 
VITA

Leasa Dianne Wilkerson was born in Boone County, Missouri, the second child and only daughter of Robert Miller and Margaret Dianne Wilkerson. She was raised on a small-diversified farm near the town of Paris, Missouri.

Leasa received her primary, middle, and high school education from the Paris R-II school system. While in school she was active member and officer of the county 4-H club, Jr. Leaders, Future Farmers of America, County Fair Board, Missouri Junior Sheep Breeders Association, American Field Service, Art club, and Future Homemakers of America.

Leasa graduated from high school in the spring of 1991. In September of that year, she was admitted to Northwest Missouri State University in Maryville, Missouri and was recipient of the Dean Warnstaff scholarship and University Regents scholarship. While in college, Leasa was active in civic organizations such as Alpha Tau Alpha agricultural education fraternity, Delta Tau Alpha national agricultural honor fraternity, Sigma Alpha female agricultural sorority, the Agriculture Council, NWMSU Homecoming Committee, and the International Students organization. In the fall of 1994 Leasa earned her American Farmer degree and was selected as the state representative in sheep production for National 4-H congress. Also while at NWMSU, Leasa was recognized for Who's Who Among Students in American Universities and Colleges. She was a student member of the National Vocational Agriculture Teachers Association, Missouri Vocational Agriculture Teachers Association, lowa Vocational Agriculture Teacher Association, and Missouri State Teachers Association. While in 
Maryville, Leasa met Nanda Ponnappa Gudderra. She graduated from NWMSU with a Bachelor of Science in Education (Secondary) May of 1995.

In the fall of 1995, Leasa went on to continue her education in Morgantown, West Virginia. She began her Masters degree and accepted a position of research assistant from West Virginia University Extension in the Pest Management Identification laboratory. During the spring of 1996, Leasa married Nanda. She continued to be a full time student until the fall of 1996. At this point she moved to Raleigh, North Carolina and began her working career in August of 1996 by accepting a teaching position at Sherwood Githens Middle School in Durham, North Carolina. She taught Exploring Biotechnology and Natural resources to seventh and eighth graders for three years. While at Githens she received the Technology Teacher of the Year Award, Principal Award and became a member of North Carolina Teachers Association. By the spring of 1999, Leasa transferred within the school district to a local high school position. It was at Northern High school that she taught subjects such as Animal Science I, Animal Science II, Plant Science I, Plant Science II, and Agriculture Production II. While at Northern Leasa became a member of North Carolina Agriculture Teachers Association, FFA advisor of the local chapter and part of the Search and Rescue team for the Certified Emergency Response Team member. Also while in North Carolina, Leasa did many other volunteer jobs such as: Community focus group, Assistant summer camp director, Multicultural fair participant and winner, gardening committee, outreach committee and aqua instructor at NCSU. 